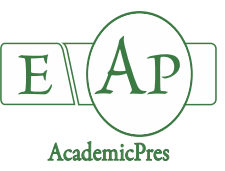

Dobrescu E et al. (2021)

Notulae Botanicae Horti Agrobotanici Cluj-Napoca

Volume 49, Issue 1, Article number 12223

DOI: $10.15835 /$ nbha 49112223

Research Article

\title{
Restorative regeneration of woody ornamental plants in the historical gardens of Peleș Royal Castle, Romania
}

\author{
Elisabeta DOBRESCU ${ }^{1 *}$, Cristina R. MĂNESCU ${ }^{1}$, \\ Mihaela I. GEORGESCU ${ }^{1}$, Florin STĂNICĂ², Ion TUCĂ $\breve{~}^{2,3}$, \\ Sorina A. PETRA ${ }^{1}$, Florin TOMA ${ }^{1}$, Diana M. GÂDEA ${ }^{1}$ \\ ${ }^{1}$ University of Agronomic Sciences and Veterinary Medicine of Bucharest, Faculty of Horticulture, Department of Landscape \\ architecture, Biodiversity and Ornamental plants, Bdul Mărăști, nr. 59, 011464, București, Romania; \\ elisabeta.dobrescu@horticultura-bucuresti.ro(*correspondingauthor);cristina.manescu@horticultura-bucuresti.ro; \\ mihaela.georgescu@horticultura-bucuresti.ro;sorina.petra@horticultura-bucuresti.ro; \\ florin.toma@horticultura-bucuresti.ro;diana.gadea@horti.usamv.ro \\ ${ }^{2}$ University of Agronomic Sciences and Veterinary Medicine of Bucharest, Faculty of Horticulture, Department of \\ Bioengineering of Horti-Viticultural Systems, Bdul Mărăști, nr. 59, 011464, București, \\ Romania; florin.stanica@usamv.ro;ion.tuca@patrimoniupeles.ro \\ ${ }^{3}$ Association for the Royal Heritage Peleș, Bdul Kiseleff, nr. 28, 011347, București, Romania
}

\begin{abstract}
Historical gardens' restoration is a complex process including not only built features of the layout, but also vegetation. Climate changes, air pollution, new pests and other factors have an important impact on vegetation and make sometimes impossible to restore the garden to the original model. Therefore, vegetation restoration requires investigations, to establish the tendencies, dynamics and resilience of different species in the garden, and decisions to adopt sustainable solutions. Woody plants from Peleș Royal Castle Gardens (Sinaia, Romania) were investigated to reveal the diachronic transformations of the vegetation and to establish an objective starting point in garden restoration. Despite of decades of neglected maintenance, historical events and changes in building function, the garden has a considerable number of old valuable trees and shrubs. Woody plants located on terraces were in a significantly poorer condition compared with those planted on the lawn. Natural forest surrounding the garden and native species cultivated in the garden acted as a source of landscape regeneration. Climate changes, affecting the mountain zone, allow the cultivation of woody species of warmer climates. Results of present study will be essential for all the future decisions about woody vegetation and gardens restoration.
\end{abstract}

Keywords: climatic changes; garden restoration; regenerative landscape; resilient ecosystem; shrub; terraces; trees

\section{Introduction}

Beyond historical evidence, royal gardens always revealed the personality of the owner. From ancient times, royal gardens delineated living spaces and ceremonial stages beyond the walls of buildings, a living

Received: 14 Jan 2021. Received in revised form: 01 Mar 2021. Accepted: 04 Mar 2021. Published online: 08 Mar 2021.

From Volume 49, Issue 1, 2021, Notulae Botanicae Horti Agrobotanici Cluj-Napoca journal will use article numbers in place of the traditional method of continuous pagination through the volume. The journal will continue to appear quarterly, as before, with four annual numbers. 
artform and a testimony of the richness and power of a country and owner (Mukerji, 1997; Novak, 2002). These gardens reflect through their design, plants and features, the new opportunities of an epoch, the tastes and preoccupations of the monarchy, being an all-consuming passion (Lane, 2020). Today, historical gardens became a resource of cultural interest (Santos and Álvarez, 2020) and a relevant cultural heritage (Carneiro et al., 2012).

Historical gardens' reconstruction is a complex process including not only built features of the layout, but also vegetation. True testimony of political, social and cultural events, with significant importance for heritage landscapes, historical garden is considered a cultural asset. The Florence Charter of 1982 suggests that historic gardens should be 'considered as a monument' consisting mainly of living components, plants (ICOMOS, 2021). The vegetal constituents evolve and change continuously, but historical gardens may be preserved in an unchanged condition for a long time with constant maintenance and replacements. In addition, trees themselves became monumental when age, size, botanic rarity, or other criteria, differentiate them in any other gardens (Asciuto et al., 2015; Zapponi et al., 2017; Ciaffi et al., 2018; Vasile et al., 2020). In this context, preservation and restoration of a historical garden impose specific guidelines that need to be respected.

Restoration was defined as 'the methodological moment of recognizing a work of art' (Brandi, 1996). As in any work of art, gardens' restoration requires discernment and expertise. The principle of maximum preservation of authenticity at the prosperity age of garden was applied in the case of some historic gardens' restoration (Shellenhamer, 2004; Halbrooks, 2005; Ignatieva et al., 2015). However, unlike constructions that are faithfully restored, in the case of gardens, the reconstruction solutions must consider as close as possible the original model, if available (Sales, 1995), but also accepting the changes and observing their dynamics (Jacques, 2014). This is because ecosystems constantly shift and change in unpredictable ways (Cronon, 1993) and historical gardens' vegetation may not be always easy to restore especially in the case of rare and exotic species (Gullino et al., 2020), due to climate change, air pollution, new pests, and other factors. Nevertheless, the past may provide clues about environmental change and it is an indispensable guide for understanding a world in flux (Alagona et al., 2012) and for this reason investigation about vegetation dynamics are necessary before starting the restoration process. Long-term vegetation dynamics over past decades may be studied by monitoring the historical plots (Kapfer et al., 2017). In the case of Peleș Gardens, Romania, the restoration of historical landscape must consider these dynamics and understand the changes of ecosystem over 100 years. In this approach, the periodic inspection of elements of the historical monument, and consequently the vegetation, is absolutely necessary. Therefore, in the present research a complete inventory and investigation of the vegetation was made, in order to obtain a preliminary scientific database and an overall assessment of the gardens. The main objective was to inventory the woody vegetation and determine its dynamics in the last 140 years, in the Peleș Royal Castle Gardens, in order to establish their role and landscape importance. The results of this study will be essential for the restoration plan of historical gardens.

\section{Materials and Methods}

\section{Geographical location and general presentation}

The Peleș Castle is located in Sinaia ( $45^{\circ} 21^{\prime} 00^{\prime \prime N}$ and 25 $\left.32^{\prime} 33^{\prime \prime E}\right)$, a town on the South-Eastern versant of Bucegi Mountain, in Prahova Region, Romania. The average altitude of this town is $860 \mathrm{~m}$. In Sinaia, the annual average temperature is $6.1{ }^{\circ} \mathrm{C}$ and the annual rainfall is $800 \mathrm{~mm}$ (PS, 2021). The dominant landcover of the area representing by forest during $19^{\text {th }}$ century, changed dramatically after the collapse of the socialist regime, when urban pressure increased due to both residential dynamics and mass-tourism (Pătru-Stupariu et al., 2011). These changes have implications on local climate, which registered in the last decades an increase in temperature, a snow depth variation and extreme weather events (Surugiu et al., 2011).

Situated in a discreet and calm place in the Bucegi Mountains, surrounded by forests, Peleș Castle Domain was the summer residence of the Romanian Royal Family. The palace was built in the style of 
sixteenth-century German Renaissance after plans of architect Johannes Schultz and it was dedicated on 1883 (Haret, 1924). Since 1890, the building was modernized and expanded into a monumental manner by architects Karel Liman and André Lecomte du Noüy (Beldiman, 2011). The gardens of Peleș Castle were meticulously imagined and created under the guidance of a great historical personality, King Carol I (the first King of Romania, from 1881 to 1914) and completed by King Ferdinand I, a passionate botanist (Stan, 2003) and Queen Mary, an art and plants lover (Mandache, 2004), his successors. Designed in terraces that surround the palace and a great lawn, the gardens were realized in decades. Over time, from 1881, when the construction of terraced gardens began, until 1914, when the last terrace was built and planted (Haret, 1924), the garden experienced different transformations and the vegetation as well. Located on slop and crossed by underground springs, the site chosen for building, required multiple technical solutions to stabilize the ground. The first garden was organized on the south terrace of the palace and several plans of vegetal compositions were adopted by Wilhelm Knechtel, the garden architect, in the following years. Also, the great lawn was planted with several exotic woody species from America and Asia (Bachelin, 1908). In 1890, when the palace was modernized, new terraces were added. In the following years, the terraced gardens were decorated in architectural style with flowers and roses, woody climbing plants and shrubs. The last terraces were added in 1910-1914 and several changes in vegetal composition were made. At the beginning of twenty-century landscape architect Friedrich Rebhun had a major contribution to the gardens' vegetal composition (Haret, 1924; Mandache, 2004). He introduced new exotic species and cultivars of trees and shrubs. The historical events that led to the abolition of the monarchy in 1947, had a significant impact on Peleș Castle Gardens. The permanent efforts of the royal family to maintain and improve the gardens, and also, the interest for the newest species and cultivars of both woody plants and flowers, were dramatically lost in the communist period (1948-1989). In 1953, the building became a museum (MNP, 2021) and the gardens were populated with much more resistant species. Some of the statues and other garden art objects were removed or replaced. The museum was closed in 1975 (MNP, 2021) and the interventions in the gardens were gradually diminished, vegetation being poorly maintained and, in some parts, completely abandoned. After Revolution in 1989, the museum was reopened (MNP, 2021), but the gardens were almost neglected, except for the vegetation on the terraces which received minimal care. In 2007, the property reverted to the royal family (MNP, 2021).

\section{Castle' gardens, division of zones and data collection}

The gardens of Peleș Royal Castle have an area of almost 4 ha, surrounded by mixed forests (Fagus sylvatica, Abies alba and Picea abies). Research was started in 2015, when the garden was evaluated and divided into five zones: zone $\mathrm{A}$, zone $\mathrm{B}$, zone $\mathrm{C}$, zone $\mathrm{D}$ and zone $\mathrm{E}$ (Figure 1 ).

In each zone, field studies and analysis, including the inventory and assessment of woody plants, were initiated in 2019. Previous to data collection, an initial study based on the interpretation of historical sources (plans, photographs, chronicles and other documents) was made. Unfortunately, the gardens were not found represented in a single and complete planting plan, because of the permanent works of transformation, modernization and planting, that were carried out over time.

\section{Identification of woody plants and their attributes; statistical analyses}

The field studies and investigations regarded the identification of woody plants and their attributes. In the case of trees, height, diameter at breast height $(\mathrm{dbh})$, crown base height and crown diameter were individually measured. For shrubs, only height and diameter were measured. Plant condition was categorized as good (healthy, vigorous plants, with perfect structure), fair (healthy, vigorous plants in general, with maximum $25 \%$ wounds or dead branches), poor (plants vigour affected, unhealed wounds or chronic parasitic attack to maximum 50\%), irreversible decline (plants with large dead branches, cavities or signs of internal decay to maximum $75 \%$ ) and dead. 


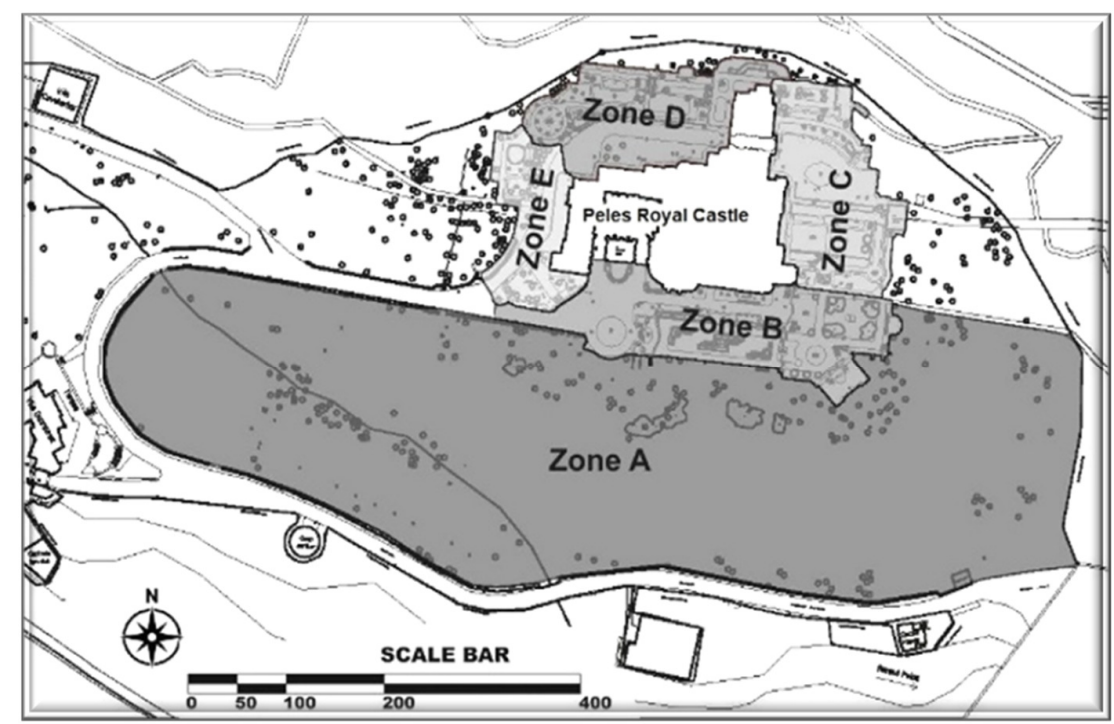

Figure 1. Zoning of Peleș Royal Castle Gardens

Zone A - The Great Lawn; Zone B - The Southern Terrace; Zone C - The Eastern Terrace; Zone D - The Northern

Terrace; Zone E - The Western Terrace

Chi-square tests were performed on species counts to reveal any disproportional use of native and exotic species, and to emphasize differences in plants' condition, between the two major zones in the garden, The Great Lawn (zone A) and Terraces (zone B, C, D and E). Correlations regarding the relationship between the planting date and plants' state of health were investigated using Pearson Test at $\mathrm{P} \leq 0.05$ and linear regression analyses.

\section{Results}

The inventory of a total number of 124 trees and 165 shrubs revealed the existence of 35 species, 12 cultivars and 2 hybrids, from 17 botanical families, in the Historical Gardens of Peleș Royal Castle (Table 1). Most of the species (60\%) are exotic, being native to Asia and North America. Significantly more exotic plants than native ones were found in terraces compared to The Great Lawn $\left(\chi^{2}=112.3783 ; \mathrm{df}=1, \mathrm{~N}=271, p<\right.$ $0.00001)$. A remarkable share of $45 \%$ of the total number of plants was represented only by five species: Thuja occidentalis, Juniperus sabina, Cornus sanguinea, Buxus sempervirens and Picea abies. Except Thuja occidentalis, these species were not found distributed uniformly in the garden. A greater diversity of species was noticed in zone A, where together with the 22 different species, appear also five of the twelve cultivars of the garden.

In zone A (The Great Lawn) were measured the tallest trees in the garden: Fagus sylvatica of $33 \mathrm{~m}$ height, Larix decidua of $29 \mathrm{~m}$ and Acer pseudoplatanus of $28 \mathrm{~m}$ (Table 2). All these species are native and perfectly adapted to the mountain region of Romania. The remarkable exotic trees of Cupressus nootkatensis (zone E, The Western Terrace) and Aesculus hippocastanum (zone A, The Great Lawn) were found in the garden, reaching a height of $24 \mathrm{~m}$ and $21 \mathrm{~m}$, respectively.

Even if the total height was not extremely high, there were several individuals with exceptional dbh values, reaching $210 \mathrm{~cm}$ at Picea abies, $185 \mathrm{~cm}$ at Platycladus orientalis, $180 \mathrm{~cm}$ at Chamaecyparis lawsoniana, $120 \mathrm{~cm}$ at Thuja occidentalis and $117 \mathrm{~cm}$ at Acer platanoides. About $35 \%$ of the total number of trees were found with dbh values larger than $50 \mathrm{~cm}$. Most trees with high dbh values were noticed in zone A (The Great Lawn), zone B (The Southern Terrace) and zone C (The Eastern Terrace). 
The crown base height values varied with the species, ranging from $0.1 \mathrm{~m}$ to $8.0 \mathrm{~m}$. The crown diameter was greater than $10 \mathrm{~m}$ at some individuals of deciduous trees such as: Fagus sylvatica, Fraxinus excelsior, Acer pseudoplatanus, Aesculus hippocastanum and Betula pendula. Some individuals of conifer trees reached values over $10 \mathrm{~m}$ at Larix decidua, Taxus baccata, Cupressus nootkatensis and Picea abies.

Table 1. Inventory of woody species, cultivars and hybrids in the Garden of Peleș Royal

\begin{tabular}{|c|c|c|c|c|c|c|c|c|}
\hline \multirow[b]{2}{*}{ Scientific name* } & \multirow[b]{2}{*}{ Family* } & \multirow[b]{2}{*}{ Origin* } & \multicolumn{5}{|c|}{ No. of individuals } & \multirow{2}{*}{$\begin{array}{l}\text { Total } \\
\text { plants }\end{array}$} \\
\hline & & & $\begin{array}{c}\text { Zone } \\
\text { A }\end{array}$ & $\begin{array}{c}\text { Zone } \\
\text { B }\end{array}$ & $\begin{array}{c}\text { Zone } \\
\text { C }\end{array}$ & $\begin{array}{c}\text { Zone } \\
\mathrm{D}\end{array}$ & $\begin{array}{c}\text { Zone } \\
\text { E }\end{array}$ & \\
\hline Abies alba & Pinaceae & native & 3 & - & - & - & - & 3 \\
\hline Acer palmatum 'Aureum' & Aceraceae & cultivar & 1 & - & - & - & - & 1 \\
\hline Acer macrophyllum & Aceraceae & N America & 1 & - & - & - & - & 1 \\
\hline Acer platanoides & Aceraceae & native & 3 & - & - & - & - & 3 \\
\hline Acer pseudoplatanus & Aceraceae & native & 11 & - & - & - & - & 11 \\
\hline Acer pseudoplatanus 'Purpureum’ & Aceraceae & cultivar & 2 & - & - & - & - & 2 \\
\hline Aesculus hippocastanum & Sapindaceae & Europe & 3 & - & - & - & - & 3 \\
\hline Berberis thunbergii & Berberidaceae & Asia & - & - & - & 2 & 1 & 3 \\
\hline Betula pendula & Betulaceae & native & 2 & - & - & - & - & 2 \\
\hline Buxus sempervirens & Buxaceae & Europe & - & 4 & 13 & 6 & 10 & 33 \\
\hline Chaenomeles speciosa & Rosaceae & Asia & - & - & - & - & 1 & 1 \\
\hline Chamaecyparis lawsoniana & Cupressaceae & N America & - & - & 6 & - & - & 6 \\
\hline Chamaecyparis lawsoniana 'Ellwoodii' & Cupressaceae & cultivar & 1 & - & - & - & - & 1 \\
\hline $\begin{array}{c}\text { Chamaecyparis pisifera 'Squarrosa } \\
\text { Lutea' }\end{array}$ & Cupressaceae & cultivar & - & - & - & 4 & 5 & 9 \\
\hline Cornus sanguinea & Cornaceae & native & 17 & - & 4 & - & 1 & 22 \\
\hline Crataegus mexicana & Rosaceae & N America & - & - & - & - & 1 & 1 \\
\hline Cupressus nootkatensis & Cupressaceae & N America & - & - & - & - & 1 & 1 \\
\hline Deutzia scabra & Hydrangeaceae & Asia & 1 & - & - & - & 5 & 6 \\
\hline Fagus sylvatica & Fagaceae & native & 5 & - & - & - & - & 5 \\
\hline Fagus sylvatica 'Purpurea' & Fagaceae & cultivar & 4 & - & - & - & - & 4 \\
\hline Forsythia $x$ intermedia & Oleaceae & hybrid & - & 4 & - & 3 & 10 & 17 \\
\hline Fraxinus excelsior & Oleaceae & native & 1 & - & - & - & - & 1 \\
\hline Hedera helix & Araliaceae & native & - & 2 & 4 & - & - & 6 \\
\hline Juniperus communis 'Hibernica' & Cupressaceae & cultivar & - & 2 & 1 & - & - & 3 \\
\hline Juniperus horizontalis & Cupressaceae & N America & - & 6 & 4 & - & - & 10 \\
\hline Juniperus sabina & Cupressaceae & native & 21 & - & - & - & - & 21 \\
\hline Laburnum anagyroides & Fabaceae & native & 1 & - & - & - & - & 1 \\
\hline Larix decidua & Pinaceae & native & 3 & - & - & - & 2 & 5 \\
\hline Lonicera pileata & Caprifoliaceae & Asia & - & - & - & 3 & 3 & 6 \\
\hline Magnolia kobus & Magnoliaceae & Asia & - & - & - & - & 8 & 8 \\
\hline Malus pumila Niedwetzkyana' & Rosaceae & cultivar & - & - & - & - & 1 & 1 \\
\hline Philadelphus coronarius & Hydrangeaceae & N America & - & 1 & - & 1 & 2 & 4 \\
\hline Picea abies & Pinaceae & native & 10 & 1 & 3 & - & - & 14 \\
\hline Picea pungens 'Argentea' & Pinaceae & cultivar & 3 & - & - & - & - & 3 \\
\hline Pinus nigra & Pinaceae & native & 3 & - & - & - & - & 3 \\
\hline Platycladus orientalis & Cupressaceae & Asia & 3 & 3 & 3 & - & - & 9 \\
\hline Prunus laurocerassus & Rosaceae & Europe & - & - & - & - & 4 & 4 \\
\hline Prunus serrulata 'Kiku-Shidare-Sakura' & Rosaceae & cultivar & - & - & - & 1 & - & 1 \\
\hline Pyracantha coccinea & Rosaceae & Europe & - & - & - & - & 1 & 1 \\
\hline Rhodotypos scadens & Rosaceae & Asia & 1 & - & - & - & - & 1 \\
\hline Sambucus nigra & Adoxaceae & native & - & - & 1 & - & - & 1 \\
\hline Spiraea $x$ vanhouttei & Rosaceae & hybrid & 1 & - & - & - & - & 1 \\
\hline Symphoricarpos albus & Caprifoliaceae & N America & 1 & - & 3 & - & 2 & 6 \\
\hline Syringa josikaea & Oleaceae & native & 1 & 1 & - & 1 & 2 & 5 \\
\hline Taxus baccata & Taxaceae & native & 3 & - & - & - & - & 3 \\
\hline Thuja occidentalis & Cupressaceae & N America & 4 & - & 2 & - & - & 6 \\
\hline Thuja occidentalis 'Columnaris' & Cupressaceae & cultivar & 3 & 6 & - & 6 & 6 & 21 \\
\hline Thuja occidentalis 'Woodwardii' & Cupressaceae & cultivar & - & 3 & - & - & - & 3 \\
\hline Thuja occidentalis 'Golden Globe' & Cupressaceae & cultivar & - & 6 & - & - & - & 6 \\
\hline Total plants & & & 113 & 39 & 44 & 27 & 66 & 289 \\
\hline
\end{tabular}

*Source of data: Iliescu (2008) and Hoffman (2016) 
Around $68 \%$ of the total woody plants inventoried at Peleș Royal Castle were in good condition. However, in zone $\mathrm{E}$, most of the plants (about $90 \%$ of the total) were in fair condition, because of the presence of numerous shrubs, which were poorly maintained (no pruning, no watering, no fertilization) for a long time. The plants presented a significantly more altered condition in the terrace zones than in the lawn zone (Figure $\left.2, \chi^{2}=13.4154 ; \mathrm{df}=1, \mathrm{~N}=289, p=0.00025\right)$. No significant relationship between age of plants and their state of health was found $\left(r=0.0281 ; \mathrm{r}^{2}=0.0008 ; p=0.634\right)$.

Table 2. Dendrometric data of trees in Peleș Royal Castle Gardens

\begin{tabular}{|c|c|c|c|c|c|c|c|c|}
\hline \multirow[t]{2}{*}{ Scientific name* } & \multicolumn{2}{|c|}{$\begin{array}{l}\text { Total height } \\
(\mathrm{m})\end{array}$} & \multicolumn{2}{|c|}{$\begin{array}{c}\text { Diameter at the } \\
\text { breast height }(\mathrm{cm})\end{array}$} & \multicolumn{2}{|c|}{$\begin{array}{l}\text { Crown base } \\
\text { height }(\mathrm{m})\end{array}$} & \multicolumn{2}{|c|}{$\begin{array}{c}\text { Crown diameter } \\
(\mathrm{m})\end{array}$} \\
\hline & mean & range & mean & range & mean & range & mean & range \\
\hline Abies alba & 8.3 & $2.8-19.0$ & 23.9 & $4.8-62.0$ & 1.2 & $0.3-3.0$ & 3.0 & $1.4-6.2$ \\
\hline Acer palmatum 'Aureum' & 10.0 & 10.0 & 60.0 & 60.0 & 2.5 & 2.5 & 8.0 & 8.0 \\
\hline Acer macrophyllum & 6.0 & 6.0 & 56.0 & 56.0 & 1.0 & 1.0 & 7.0 & 7.0 \\
\hline Acer platanoides & 8.5 & $2.0-15.0$ & 55.0 & $40.0-70.0$ & 1.75 & $0.8-2.7$ & 6.4 & $0.9-12.0$ \\
\hline Acer pseudoplatanus & 15.4 & $9.0-28.0$ & 43.9 & $28.0-70.0$ & 2.9 & $1.4-4.1$ & 11.9 & $6.0-18.0$ \\
\hline Acer pseudoplatanus 'Purpureum' & 21.00 & $20.0-22.0$ & 50.5 & $31.0-70.0$ & 5.0 & $2.0-8.0$ & 10.0 & $6.0-14.0$ \\
\hline Aesculus hippocastanum & 13.8 & $8.0-21.0$ & 55.3 & $26.0-90.0$ & 2.4 & $2.4-2.5$ & 10.0 & $6.2-14.5$ \\
\hline Betula pendula & 12.0 & $9.0-15.0$ & 35.0 & $30.0-40.0$ & 3.1 & $2.6-3.6$ & 8.0 & $5.0-11.0$ \\
\hline Chamaecyparis lawsoniana & 8.4 & $7.0-9.0$ & 114.5 & $78.0-180.0$ & 2.3 & $0.8-3.0$ & 4.5 & $4.0-5.0$ \\
\hline Chamaecyparis lawsoniana 'Ellwoodii' & 11.5 & 11.5 & 50.0 & 50.0 & 0.6 & 0.6 & 11.0 & 11.0 \\
\hline Crataegus mexicana & 2.8 & 2.8 & 0.2 & 0.2 & 0.9 & 0.9 & 3.9 & 3.9 \\
\hline Cupressus nootkatensis & 24.0 & 24.0 & 121.0 & 121.0 & 0.5 & 0.5 & 9.5 & 9.5 \\
\hline Fagus sylvatica & 18.0 & $17.0-20.0$ & 81.0 & $80.0-90.0$ & 4.1 & $2.3-8.0$ & 13.8 & $7.0-20.0$ \\
\hline Fagus sylvatica 'Purpurea' & 27.0 & $24.0-33.0$ & 82.5 & $80.0-110.0$ & 3.0 & $2.0-4.7$ & 14.0 & $7.5-19.5$ \\
\hline Fraxinus excelsior & 20.0 & 20.0 & 65.0 & 65.0 & 2.3 & 2.3 & 18.0 & 18.0 \\
\hline Juniperus communis 'Hibernica' & 2.0 & $2.0-4.0$ & 0.7 & $0.6-1.0$ & 0.1 & $0.1-0.2$ & 0.7 & $0.5-1.2$ \\
\hline Laburnum anagyroides & 7.0 & 7.0 & 15.0 & 15.0 & 0.9 & 0.9 & 9.0 & 9.0 \\
\hline Larix decidua & 23.1 & $9.5-29.0$ & 45.6 & $30.0-60.0$ & 6.1 & $4.0-7.2$ & 7.8 & $6.0-12.0$ \\
\hline Magnolia kobus & 11.6 & $10.0-13.0$ & 36.8 & $31.8-41.4$ & 1.3 & $1.0-2.0$ & 6.4 & $5.0-8.0$ \\
\hline Malus pumila 'Niedwetzkyana' & 5.0 & 5.0 & 0.3 & 0.3 & 1.0 & 1.0 & 8.0 & 8.0 \\
\hline Picea abies & 18.9 & $9.0-26.0$ & 95.2 & $30.0-210.0$ & 4.8 & $2.7-7.0$ & 7.2 & $3.0-10.0$ \\
\hline Picea pungens 'Argentea' & 16.3 & $16.0-17.0$ & 56.6 & $40.0-65.0$ & 2.7 & $1.6-4.2$ & 8.1 & $6.7-9.5$ \\
\hline Pinus nigra & 17.0 & $14.0-19.0$ & 41.0 & $28.0-50.0$ & 4.2 & $3.0-5.0$ & 6.1 & $4.0-9.5$ \\
\hline Platycladus orientalis & 9.2 & $8.0-12.0$ & 42.5 & $17.0-185.0$ & 3.3 & $1.0-5.0$ & 3.1 & $2.0-8.0$ \\
\hline Prunus serrulata 'Kiku-Shidare-Sakura' & 3.5 & 3.5 & 35.0 & 35.0 & 1.8 & 1.8 & 4.6 & 4.6 \\
\hline Taxus baccata & 7.9 & $5.0-9.2$ & 23.1 & $9.6-45.0$ & 0.8 & $0.7-2.5$ & 9.1 & $7.0-11.0$ \\
\hline Thuja occidentalis & 11.8 & $6.0-19.0$ & 37.6 & $10.0-120.0$ & 2.2 & $0.8-5.0$ & 3.9 & $2.0-8.0$ \\
\hline Thuja occidentalis 'Columnaris' & 6.1 & $6.0-8.0$ & 22.2 & $15.0-74.0$ & 0.3 & $0.1-0.5$ & 2.7 & $1.8-3.5$ \\
\hline
\end{tabular}

${ }^{*}$ Source of data: Iliescu (2008) and Hoffman (2016)

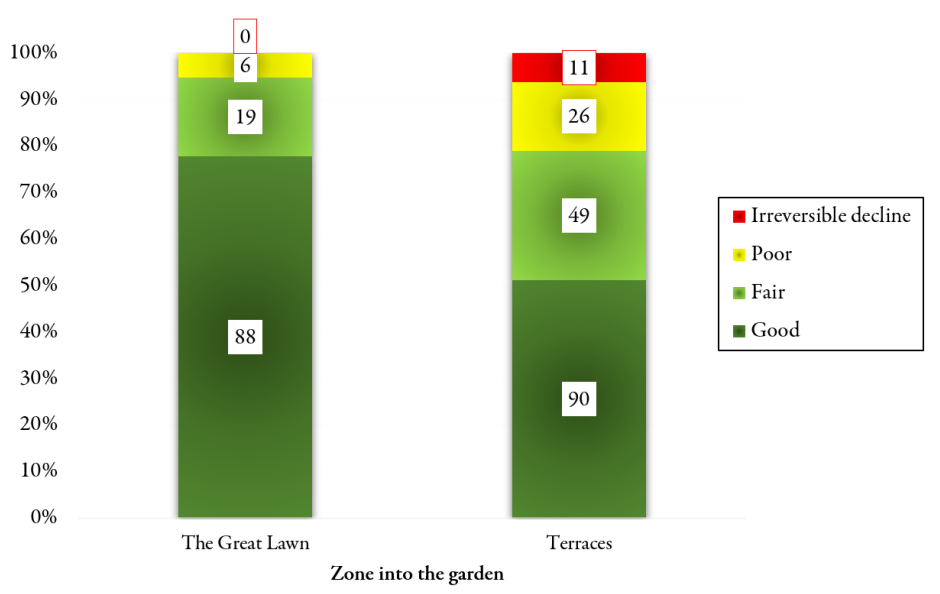

Figure 2. Number of woody plants situated in The Great Lawn and Terraces, according to their condition 
A diachronic study of woody vegetation revealed that most of the plants $(80 \%)$ in the garden were planted after 1948, when the royal domain was nationalized (Figure 3).

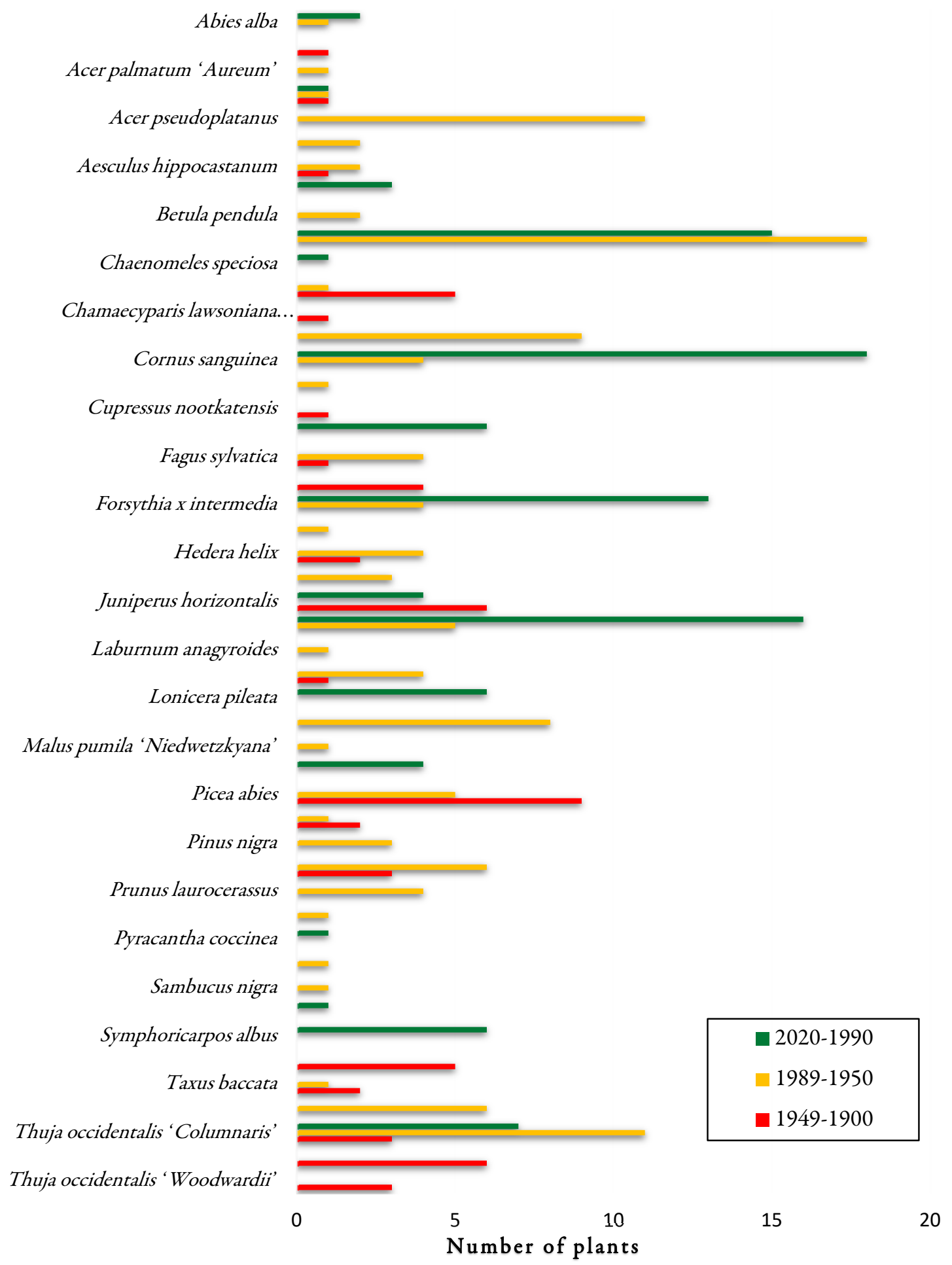

Figure 3. Number of plants cultivated at different moments in time 
However, a few old individuals of tree and shrubs continued to grow and survived over times and may be seen today especially in zone A. Lack of maintenance, in the last 50-70 years, led not only to the loss of some trees and shrubs, but also the advance of forest in the northern terrace of the garden (Figure 4).
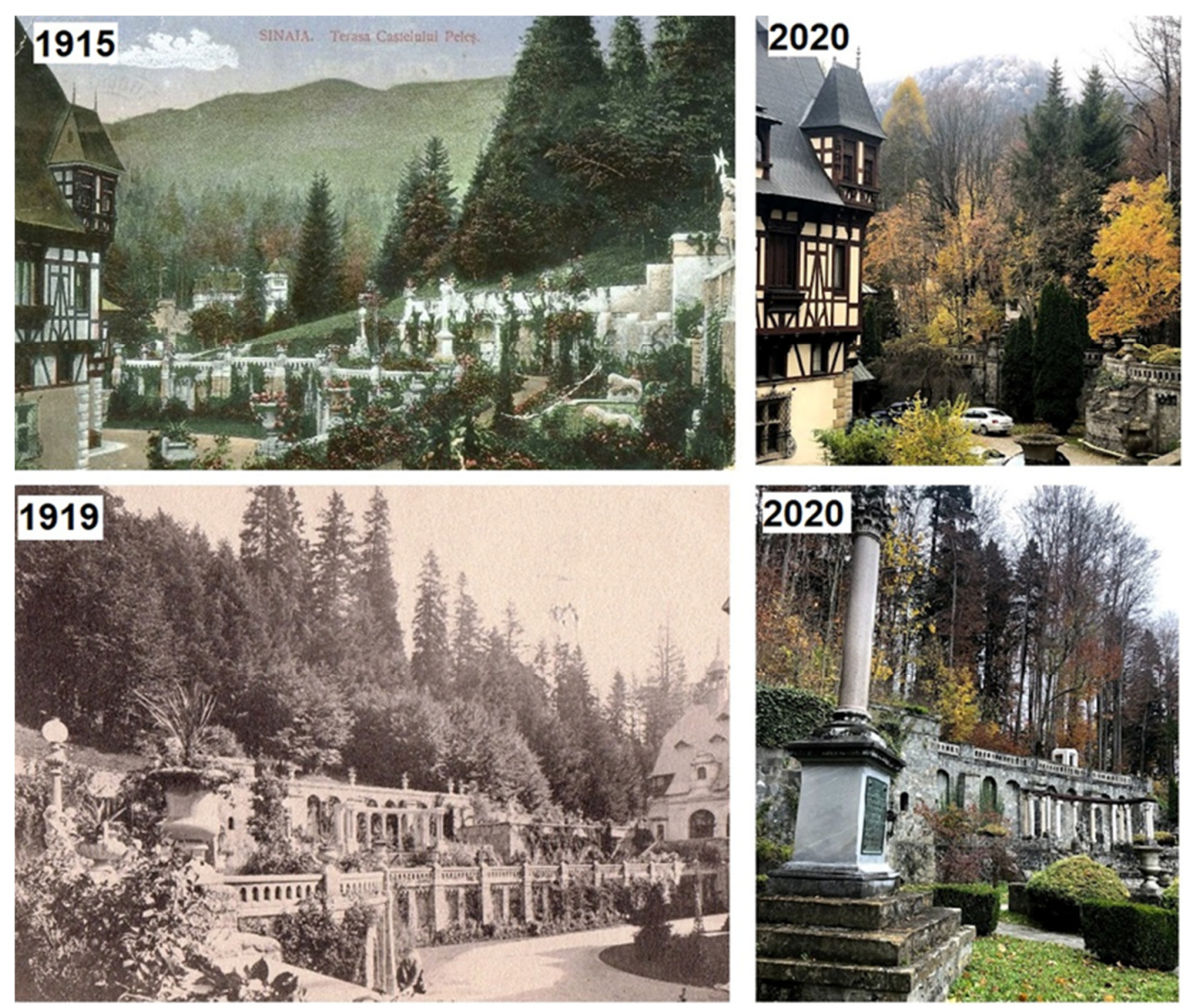

Figure 4. The Northern Terrace and the forest

Old photos are post-cards of MNIR (2020)

The analysis of both plans and old photos revealed major changes in the structure of forest, too. Pictures taken in 1915 and 1919 from the northern terrace of the garden revealed a mixed forest, where the conifers were predominant. Today, at the forest limit, in the proximity of the terrace, Fagus sylvatica is more often seen. Also, the abandonment and lack of maintenance for several decades created a new and consistent layer of soil, in some parts almost $40 \mathrm{~cm}$ thick, which covered soil, alleys, stairs and retaining garden walls (Figure 5).
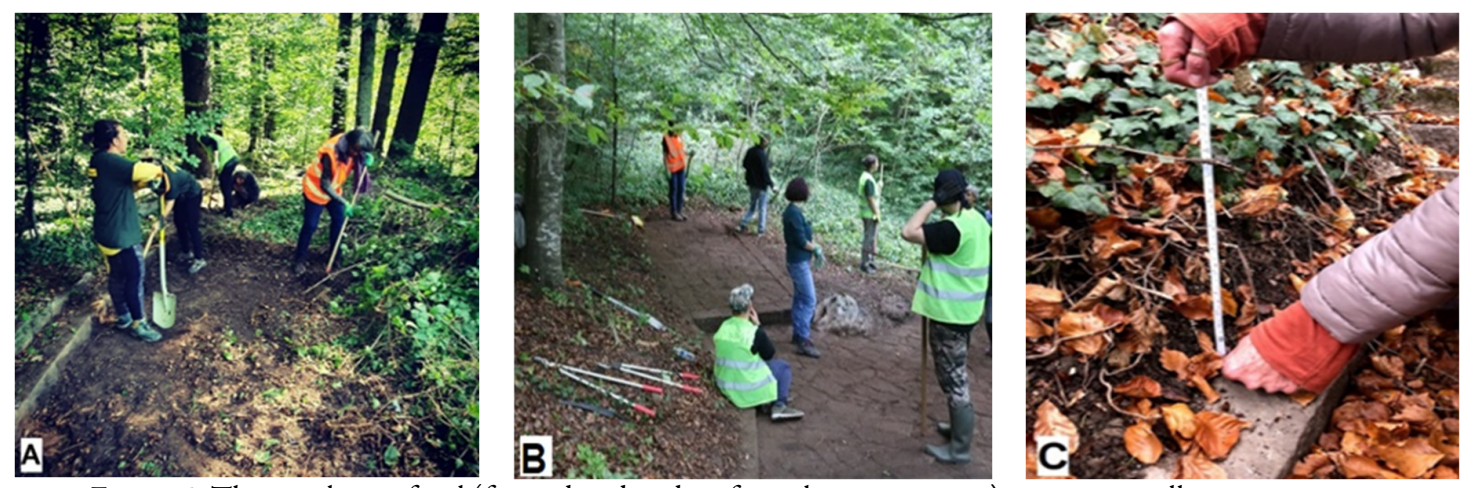

Figure 5. The new layer of soil (formed in decades of poorly maintenance) covering an alley

(A) vegetation removal; (B) alley clean up; (C) layer of $25 \mathrm{~cm}$, visible near the cleaned alley 


\section{Discussion}

The woody plants assortment recorded in the present garden of Peleș Royal Castle reflects the influences of time, climate, topography, geomorphology and management practices. In the royal period (1883-1947), many special, rare and exotic species were used to decorate terraces and The Great Lawn. Some individuals of these species are still found in the garden. Also, a considerable proportion of species native to Asia and North America (about 60\%), planted in the period of King Carol I by landscape architects Wilhelm Knechtel and Karel Liman, remained in the gardens. However, predominant woody plants in the garden were common, native species, such as Picea abies, Juniperus sabina and Cornus sanguinea. This may be explained not only by the abandon of maintenance of garden during the communist period (1948-1989) and after Revolution in 1989 , but also by the completing in this time of the assortment with native and much more resistant species. Furthermore, the natural forest, that surrounds the garden, subjected to minimal disturbance over the years, acted as a source of recolonization. Thus, ecological memory required for reorganization of forestry ecosystem was found both inside and outside the area of disturbance (Bengtsson et al., 2003). Also, the change of building function from the residence of the royal family to a museum had an important impact on the current composition of the garden. Peleș Royal Castle is one of the five most visited museums in Romania, according to Eurostat (2019). However, the opening of historic gardens to public required changes to improve the conditions of visiting by tourists and safety measures being implemented (Santos and Álvarez, 2020). For this reason, the tallest trees of the garden were found apart of the visitation area, in zone A, where no pruning work to reduce tree height was ever applied.

Although the garden is in a mountainous area, some species of warmer climates (such as Acer palmatum, Chamaecyparis lawsoniana, Chamaecyparis pisifera, Magnolia kobus, Prunus laurocerasus), which usually are not recommended in cold areas of Romania (Iliescu, 2008), were identified. The adaptation of exotic species to a different temperature regime as of their native range was observed and studied by some other authors (Kollas et al., 2014; Kreyling et al., 2015; Muffler et al., 2016), who found it into a close relationship with the occurrence of frost in late winter or early spring. In Central Europe, the incidence of late frost that damage plants were low in past decades, because of the global warming (Scheifinger et al., 2003; Wypych et al., 2017). Particularly in the Bucegi Mountains, winters were characterized as mild, with little snow and early springs, that significantly disturbed the plant communities (Sârbu et al., 2014). Anyway, climate changes may extend the list of species that can be adopted in colder climates (Messinger, 2015). In case of Peleș Castle, several species sensitive in the past to the mountain climate and lost over winter, such as Rosaspp. and Wisteria sinensis, could be reintroduced in the gardens. Moreover, our investigation on plants condition revealed that species of colder climate, such as Picea abies, Larix decidua, Betula pubescens and Acer pseudoplatanus, are affected, and even lost, by current climate conditions and impose replacements with similar species much more adapted. Similar observations were reported by other authors for the northern zones of Europe (Kramer, 1995; Schuman et al., 2011; Thurm et al., 2018). In the case of Peleș Castle Gardens, alternative conifer species could be: Picea pungens, Pseudotsuga menziesii and Abies alba, and for broadleaved species: Betula pendula and Acer platanoides.

Results showed a significant difference between plants' condition located on terraces and those on the lawn. Woody vegetation present on terraces appeared much more deteriorated. Terraces are built to preserve more water, to decrease erosion (Lasanta et al., 2001; Arnáez et al., 2015; Kovář et al., 2016; Qihua et al., 2020), to provide a larger surface area for the garden, to make walking much easier and comfortable and to create a large view of the garden (Cunningham, 1996). The environments created by terraces are not always favourable for woody species and, therefore, they react differently (Maikhuri et al., 2000; Siriri et al., 2010; Van der Sluis et al., 2014). In the case of Peleș Castle, some of the plants located on terraces were in a poor condition because of sum of factors, such as: species, age and lack of maintenance. Investigations regarding the species in relation to their age and state of health have shown some differences. In case of several species, such as Acer pseudoplatanus, Buxus sempervirens, Larix decidua, Picea abies, Platycladus orientalis and Prunus serrulata, 
their both planting time and condition were not related. For other species, such as Chamaecyparis lawsoniana, Fagus sylvatica, Juniperus horizontalis and Thuja occidentalis, their state of health has depended on their age.

Some of the plants on the terraces have no landscape value or function, at all and may be completely removed (in zone A: obstructive viewpoint and hazardous Thuja, obstructive viewpoint Deutzia and degraded Picea hedges; in zone B: hedges of Buxus, invasive Hedera and Juniperus shrubs, and degraded Thuja and Juniperus tree plants; in zone C: obstructive viewpoint Chamaecyparis and invasive Hedera; in zone D: degraded plants of Lonicera; in zone E: degraded plants of Buxus, Juniperus and Forsythia, weak trees of Crataegus and Thuja). Also, the line of forest in zone D must be reconfigured, due to the pressure exerted on the terrace.

Field observations and analysis of both pictures and plans revealed not only an important movement of forest to the terrace but also a change in time of forest edge composition. Lawn strip splitting the forest from the terrace was covered by Fagus trees, despite low density of these species in the forest at that time. Forest regeneration and replacement of conifers by Fagus in European forests were also reported by other authors (Paluch, 2005; Nagel et al., 2006; Nagel et al., 2010), and seems to be associated with edaphic changes. The new and consistent layer of soil formed in northern zone of the garden of Peleș Castle, created conditions for forest restoration. This natural regeneration of landscape should not be ignored, because it offers valuable clues about capacity of forest to recover and restore the environment.

\section{Conclusions}

Preserving the aspect of the historical garden of Peleș Royal Castle as a place for meeting the old times in modern times, it is a challenging issue. The future garden restoration must consider not only the historical landscape, which must send an authentic and strong message as the cradle of Romanian monarchy, but also the environmental changes, regenerative capacity of landscape and species resilience. Investigations revealed that garden has a reasonable biodiversity of species and contain old valuable trees and shrubs, despite of historical events and neglected maintenance. Therefore, restoration plan must include their control and protection on a regular basis. This also includes the removal of some plants with low landscape value, degraded or invasive and

replant all the woody species that garden had lost by abandonment. Restoration of Peleș Royal Castle garden must consider the flux of visitors and their safety and adapt the old plans to the actual function of building, that of as a museum.

\section{Authors' Contributions}

Conceptualization and writing: ED and CRM; Investigation: ED, MIG, FS, IT, SAP, FT, DMG. All authors read and approved the final manuscript.

\section{Acknowledgements}

This research received no specific grant from any funding agency in the public, commercial, or not-forprofit sectors. 


\section{Conflict of Interests}

The authors declare that there are no conflicts of interest related to this article.

\section{References}

Alagona PS, Sandlos J, Wiersma YF (2012). Past imperfect: using historical ecology and baseline data for conservation and restoration projects in North America. Environmental Philosophy 9(1):49-70.

Arnáez J, Lana-Renault N, Lasanta T, Ruiz-Flaño P, Castroviejo J (2015). Effects of farming terraces on hydrological and geomorphological processes. A review. Catena 128:122-134. https://doi.org/10.1016/j.catena.2015.01.021

Asciuto A, Borsellino V, D’Acquisto M, Di Franco CP, Di Gesaro M, Schimmenti E (2015). Monumental trees and their existence value: The case study of an Italian natural park. Journal of Forest Science 61(2):55-61. https://doi.org/10.17221/86/2014-JFS

Bachelin L (1908). Castelul Peleș. Schiță istorică și descriptivă [Peleș Castle. Historical and descriptive sketch]. Librariei Leon Alcalay Publishing House. Bucharest.

Beldiman R (2011). Castelul Peleș, expresie a fenomenului istorist de influență germană [Peleș Castle, an expression of German historicism]. Simetria Publishing House. Bucharest.

Bengtsson J, Angelstam P, Elmqvist T, Emanuelsson U, Floke C, Ihse M, ... Nyström M (2003). Reserves, resilience and dynamic landscapes. Ambio 23(6):389-396. https://doi.org/10.1579/0044-7447-32.6.389

Brandi C (1996). Theory of restoration (Italian original published 1963; translated in Romanian by Balaci R). Meridiane Publishing House. Bucharest.

Carneiro ARS, da Silva JM, Veras de Siqueira LM, de Figueirôa A (2012). The complexity of historic garden life conservation. In: Zancheti SM, Similä K (Eds). Measuring heritage conservation performance. ICCROM, Rome pp 33-41.

Cronon W (1993). The uses of environmental history. Environmental History Review 17(3):1-22. https://doi.org/10.2307/3984602

Cunningham A (1996). The culture of gardens. In: Jardine N, Secord JA, Spary EC (Eds). Cultures of Natural History. Cambridge University Press, Cambridge pp 38-56.

Eurostat (2019). Culture statistics - 2019 edition. Publications Office of the European Union. Luxembourg. https://doi.org/10.2785/118217

Gullino P, Devecchi M, Larcher F (2020). New sustainable approach for historical garden restoration: the case study of Ludwig Winter's Gardens in Liguria Region. Acta Horticulture 1279:9-14. https://www.actahort.org/books/1279/1279_2.htm

Halbrooks MC (2005). The english garden at Stan Hywet Hall and Gardens: interpretation, analysis and documentation of a historic garden restoration. HortTechnology 15(2):196-213. https://doi.org/10.21273/horttech.15.2.0196

Haret M (1924). Castelul Peleș, monografie istorică, geografică, turistică, pitorească, descriptivă [Peleș Castle, historic, geographic, touristic, picturesque, descriptive monograph]. Cartea Românească Publishing House. Bucharest.

Hoffman MHA (2016). List of names of woody plants: international standard ENA 2016-2020. 9th Edition. Reolofarendsveen: Naktuinbouw.

ICOMOS (2021). International Council on Monuments and Sites. Retrieved 2021 February 22 from https://www.icomos.org

Ignatieva M, Melnichuk I, Cherdantseva O, Lukmazova E (2015). History and restoration of the St Petersburg Summer Garden: returning to the roots. Garden History 43(2):199-217. https://www.jstor.org/stable/24636250

Iliescu AF (2008). Cultura arborilor și arbustilor ornamentali [Culture of ornamental trees and shrubs]. Ceres Publishing House, Bucharest.

Jacques D (2014). Evolution of principles for the conservation of gardens and designed landscapes. In: Harney M (Eds). Gardens and landscapes in historic building conservation. Wiley-Blackwell Publishing Ltd, United States pp 5566.

Kapfer J, Hedl R, Jurasinski G, Kopecky M, Schei FH, Grytnes JA (2017). Resurveying historical vegetation data opportunities and challenges. Applied Vegetation Science 20:164-171. https://doiorg/10.1111/avsc. 12269

Kollas C, Körner C, Randin CF (2014). Spring frost and growing season length co-control the cold range limits of broadleaved trees. Journal of Biogeography 41(4):773-783. https://doi.org/10.1111/jbi.12238 
Kovář P, Bačinová H, Loula J, Fedorova D (2016). Use of terraces to mitigate the impacts of overland flow and erosion on a catchment. Plant, Soil and Environment 62(4):171-177. https://doi.org/10.17221/786/2015-PSE

Kramer K (1995). Phenotypic plasticity of the phenology of seven European tree species in relation to climatic warming. Plant, Cell and Environment 18:93-104. https://doi.org/10.1111/j.1365-3040.1995.tb00356.x

Kreyling J, Schmid S, Aas G (2015). Cold tolerance of tree species is related to the climate of their native ranges. Journal of Biogeography 42(1):156-166. https://doi.org/10.1111/jbi.12411

Lane M (2020). Royal gardens of the world: 21 celebrated gardens from the Alhambra to Highgrove and beyond. Hachette UK.

Lasanta T, Arnáez J, Oserín M, Ortigosa LM (2001). Marginal lands and erosion in terraced fields in the Mediterranean mountains. A case study in the Camero Viejo (Northwestern Iberian System, Spain). Mountain Research and Development 21:69-76. https://doi.org/10.1659/0276-4741(2001)021[0069:MLAEIT]2.0.CO;2

Maikhuri RK, Semwal RL, Rao KS, Singh K, Saxena KG (2000). Growth and ecological impacts of traditional agroforestry tree species in Central Himalaya, India. Agroforestry Systems 48(3):257-271. https://doi.org/10.1023/A:1006344812127

Mandache D (2004). Later chapters of my life: the lost memoir of Queen Marie of Romania. Sutton Publishing, Ltd. Gloucestershire.

MNP (2021). Muzeul Național Peleș [National Museum Peleș]. Retrieved 2021 February 22 from https://en.peles.ro/history

Messinger J, Güney A, Zimmermann R, Ganser B, Bachmann M, Remmele S, Aas G (2015). Cedrus libani: A promising tree species for Central European forestry facing climate change? European Journal of Forest Research 134(6):1005-1017. https://doi.org/10.1007/s10342-015-0905-Z

MNIR (2020). Muzeul Național de Istorie al României [National Museum of Romanian History] and iMAGO Romaniae. Retrieved 2020 December 22 from http://imagoromaniae.ro/imagini/carti-postale

Muffler L, Beierkuhnlein C, Aas G, Jentsch A, Schweiger AH, Zohner C, Kreyling J (2016). Distribution ranges and spring phenology explain late frost sensitivity in 170 woody plants from Northern Hemisphere. Global Ecology and Biogeography 25(9):1061-1071. https://doi.org/10.1111/geb.12466

Mukerji C (1997). Territorial ambitions and the gardens of Versailles. Cambridge University Press.

Nagel TA, Svoboda M, Diaci J (2006). Regeneration patterns after intermediate wind disturbance in an old-growth FagusAbies forest in south-eastern Slovenia. Forest Ecology and Management 226(1-3):268-278. https://doi.org/10.1016/j.foreco.2006.01.039

Nagel TA, Svoboda M, Rugani T, Diaci J (2010). Gap regeneration and replacement patterns in an old-growth FagusAbies forest of Bosnia-Herzegovina. Plant Ecology 208(2):307-318. https://doi.org/10.1007/s11258-0099707-z

Novak M (2002). The artificial paradise: programme and ideology of royal gardens. In Parpola S, Whiting RM (Eds). Sex and gender in the ancient Near East. Helsinki pp 443-460.

Paluch JG (2005). The influence of the spatial pattern of trees on forest floor vegetation and silver fir (Abies alba Mill) regeneration in uneven-aged forests. Forest Ecology and Management 205:283-298. https://doi.org/10.1016/j.foreco.2004.10.010

Pătru-Stupariu I, Stupariu MS, Cuculici R, Huzui A (2011). Understanding landscape change using historical maps. Case study Sinaia, Romania. Journal of Maps 7(1):206-220. https://doi.org/10.4113/jom.2011.1151

PS (2021). Primaria Sinaia [Sinaia City Hall]. Retrieved 2021 February 22 from https://www.primaria-sinaia.ro

Qihua R, Xiuxiu C, Yanyan H, Sheng Y, Jihui G (2020). Impacts of terracing on hydrological processes: A case study from the Loess Plateau of China. Journal of Hydrology 588:125045. https://doi.org/10.1016/j.jhydrol.2020.125045

Sales J (1995). Garden restoration past and present. Garden History 23(1):1-9. https://doi.org/10.2307/1587009

Santos JD, Álvarez CM (2020). Atrio de la Alhambra. Una reflexión sobre el jardín moderno en la conservatión del monumento Nazarí y su entorno [Atrium of the Alhambra. A reflection on the modern gardens in the conservation of the Nasrid monument and its surroundings]. Proyeto, Progreso, Arquitectura 22:138-157. http:dx.doi.org//10.12795/ppa.2020.i22.08

Sârbu A, Anastasiu P, Smarandache D (2014). Potential impact of climate change on alpine habitats from Bucegi Natural Park, Romania. In Rannow S, Neubert M (Eds). Managing protected areas in central and eastern Europe under climate change. Dordrecht: Springer pp 259-267. https://doi.org/10.1007/978-94-007-7960-0

Scheifinger H, Menzel A, Koch E, Peter C (2003). Trends of spring time frost events and phenological dates in Central Europe. Theoretical and Applied Climatology 74(1-2):41-51. https://doi.org/10.1007/s00704-002-0704-6 
Shellenhamer J (2004). The archaeology and restoration of the William Paca Garden, Annapolis, Maryland: 1966-1990. MSc Dissertation, University of Maryland. https://doi.org/10.13016/ilyc-bqvp

Shuman JK, Shugart HH, O'Halloran TL (2011). Sensitivity of Siberian larch forests to climate change. Global Change Biology 17(7):2370-2384. https://doi.org/10.1111/j.1365-2486.2011.02417.x

Siriri D, Ong CK, Wilson J, Boffa JM, Black CR (2010). Tree species and pruning regime affect crop yield on bench terraces in SW Uganda. Agroforestry systems 78(1):65-77. https://doi.org/10.1007/s10457-009-9215-0

Stan CI (2003). Regele Ferdinand I, "Întregitorul”: 1914-1927 [King Ferdinand I, “The Unifier”: 1914-1927]. Paideia Publishing House, Bucharest.

Surugiu C, Surugiu MR, Frent C, Breda Z (2011). Effects of climate change on Romanian Mountain Tourism: are they positive or mostly negative. European Journal of Tourism, Hospitality and Recreation 2(1):42-71.

Thurm EA, Hernandez L, Baltensweiler A, Ayan S, Rasztovits E, Bielak K, ... Falk W (2018). Alternative tree species under climate warming in managed European forest. Forest Ecology and Management 430:485-497. https://doi.org/10.1016/j.foreco.2018.08.028

Van der Sluis T, Kizos T, Pedroli B (2014). Landscape change in Mediterranean farmlands: impacts of land abandonment on cultivation terraces in Portofino (Italy) and Lesvos (Greece). Journal of Landscape Ecology 7(1):23-44. https://doi.org/10.2478/jlecol-2014-0008

Vasile D, Enescu R, Vechiu E, Coman S, Scărlătescu V (2020). Monumental trees of Brasov county. Revista de Silvicultura si Cinegetica 25(46):70-76.

Wypych A, Ustrnul Z, Sulikowska A, Chmielewski FM, Bochenek B (2017). Spatial and temporal variability of the frostfree season in Central Europe and its circulation background. International Journal of Climatology 37(8):33403352. https://doi.org/10.1002/joc. 4920

Zapponi L, Mazza G, Farina A, Fedrigoli L, Mazzocchi F, Roversi PF, ... Mason F (2017). The role of monumental trees for the preservation of saproxylic biodiversity: re-thinking their management in cultural landscapes. In: Campanaro A, Hardersen S, Sabbatini Peverieri G, Carpaneto GM (Eds). Monitoring of saproxylic beetles and other insects protected in the European Union. Nature Conservation pp 231-243. https://doi.org/10.3897/naturaconservation.1912464
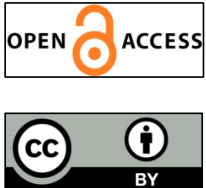

The journal offers free, immediate, and unrestricted access to peer-reviewed research and scholarly work. Users are allowed to read, download, copy, distribute, print, search, or link to the full texts of the articles, or use them for any other lawful purpose, without asking prior permission from the publisher or the author.

License - Articles published in Notulae Botanicae Horti Agrobotanici Cluj-Napoca are Open-Access, distributed under the terms and conditions of the Creative Commons Attribution (CC BY 4.0) License. (C) Articles by the authors; UASVM, Cluj-Napoca, Romania. The journal allows the author(s) to hold the copyright/to retain publishing rights without restriction. 